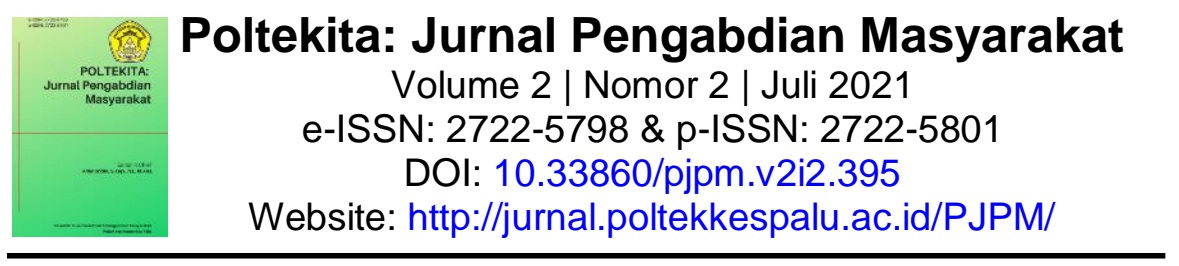

\title{
Peningkatan Pengetahuan Anak Sekolah Dasar tentang Dampak Jajan Sembarangan Bagi Kesehatan
}

\section{Ade Devriany}

Poltekkes Kemenkes Pangkalpinang, Jurusan Gizi

凹Email korespondensi: ade.devriany@gmail.com

\section{Article history: \\ Received: 23-02-2021 \\ Accepted: 01-03-2021 \\ Published: 31-07-2021 \\ Kata Kunci: \\ Pengetahuan; makanan ringan; siswa.}

\section{Keywords:}

Knowledge; snack; student.

\begin{abstract}
ABSTRAK
Kebiasaan jajan sembarangan pada anak-anak memiliki risiko serta dampak yang buruk bagi kesehatan. Bagi anak yang tidak terbiasa makan pagi, makanan jajanan berfungsi sebagai makanan yang pertama kali masuk ke saluran pencernaan, sehingga jajanan menjadi penting artinya. Namun, diketahui banyak kandungan zat kimia pada jajanan yang bertentangan dengan tubuh seperti boraks, formalin, MSG. Kegiatan ini bertujuan meningkatkan pengetahuan siswa SD tentang kandungan zat kimia dalam jajanan tersebut serta bahaya yang ditimbulkannya bagi kesehatan. Metode yang digunakan adalah penyuluhan dengan metode ceramah dan diskusi. Penyampaian materi melalui video animasi dan permainan tentang akibat jajan sembarangan dan cara memilih jajanan sehat. Berdasarkan hasil penilaian pre-test, terdapat $51,95 \%$ siwa-siswa dengan tingkat pengetahuan yang cukup dan $48,05 \%$ dengan kategori pengetahuan yang baik. Setelah mendapatkan penyuluhan, post-test meningkat yaitu $7,79 \%$ peserta dengan kategori pengetahuan cukup paham, $50,64 \%$ pengetahuan yang baik dan $41,57 \%$ sangat baik. Kesimpulannya bahwa penyuluhan tentang bahaya dan dampak jajan sembarangan dapat dimengerti oleh peserta. Dengan demikian, diharapkan peran serta aktif pihak sekolah terutama bagi siswa dalam pencegahan jajan sembarangan dapat menjadi lebih baik agar kejadian penyakit akibat jajan sembarangan dapat dikurangi.
\end{abstract}

\section{ABSTRACT}

The habit of careless snacking on children had various risks and unfavourable effects on health. For children who were not accustomed to eating breakfast, a snack could be the first food that entered the digestive system. This consequently caused snack to be an important need for some people. However, it was known that there were many chemical substances in foods that might not be beneficial for the body, such as borax, formalin, or monosodium glutamate (MSG). This activity aimed to increase elementary students' knowledge of chemical substances in these snacks and the effects on health. The method used in this study was counselling through lecture and discussion. Delivery of material was done through video animation and games about the consequences of unhealthy snacks and how to choose healthy snacks. Based on the results of pre-test observations, it was known that around $51.95 \%$ of participants have sufficient knowledge and $48.05 \%$ have good knowledge. After the extension activities were carried out, the value of the observations was improved shown through posttests results. It was known that $7.79 \%$ of the participants understood well, $50.64 \%$ had good knowledge and $41.57 \%$ were very good. It can be concluded that the outreach activities about the risk of unhealthy snacking could be understood by the participants. It was hoped that with the provision of these materials, the active participation of the school, especially elementary school students, in preventing unhealthy snack consumption could be better to reduce the number of health issue caused by unhealthy snacking.

\footnotetext{
(C) 2021 by the authors. Submitted for possible open access publication under the terms and conditions of the Creative Commons Attribution (CC BY SA) license (https://creativecommons.org/licenses/by-sa/4.0/)
} 


\section{PENDAHULUAN}

Kesehatan sejak usia dini merupakan salah satu upaya yang cukup penting dalam menciptakan sumber daya manusia yang produktif dan berkualitas di masa yang akan datang. Tumbuh kembangnya anak usia sekolah yang optimal tergantung pada nutrisi dengan kualitas dan kuantitas yang baik (Syam et al., 2018). Kebiasaan jajan pada anak sudah menjadi kebiasaan umum dan ditemui di berbagai tingkat sosial ekonomi masyarakat. Pada dasarnya anak-anak SD kebanyakan suka jajanan dibanding makanan berat. Mereka menghabiskan uang jajannya untuk membeli jajanan di kantin sekolah maupun pedagang kaki lima di sekitar sekolah. Bagi anak yang tidak terbiasa makan pagi, makanan jajanan berfungsi sebagai makanan yang pertama kali masuk ke saluran pencernaan, sehingga pada sebagian orang, jajanan menjadi penting artinya. Penelitian Mariza \& Kusumastuti (2012) menunjukkan bahwa $43.76 \%$ anak sekolah dasar tidak melakukan sarapan pagi dan lebih biasa mengonsumsi jajanan. Hal ini mengakibatkan proporsi makan (sarapan, selingan, makan siang dan makan malam) sehari tidak sesuai dengan anjuran (Mariza \& Kusumastuti, 2013).

Kebiasaan jajan pada anak sekolah dasar seperti dua sisi mata uang. Baik dan buruknya berjalan beriringan karena banyak kandungan zat kimia yang digunakan bertentangan dengan tubuh seperti boraks, formalin, MSG dan masih banyak zat-zat yang lain. Dilain sisi, jajanan ini diperlukan sebagai makanan tambahan anak. Keterampilan anak dalam memilih jajanan di sekolah merupakan faktor kritis untuk mendapatkan makanan yang sesuai kebutuhan dan memenuhi syarat kesehatan (Sembiring \& Ampera, 2018). Menurut penelitian Sari \& Rachmawati (2020), makanan jajanan memberikan kontribusi sebesar 29,5\% asupan energi, 2,9\% asupan protein, $8,6 \%$ asupan lemak dan $15,6 \%$ asupan karbohidrat pada anak sekolah dasar atau kelompok umur 6-12 tahun. Jajanan anak sekolah dasar sangat beragam jenisnya, yang paling sering ditemukan antara lain yaitu otak-otak, tahu goreng, mie bakso dengan saus, es sirop, sate sosis dengan saus, empek-empek dan lain sejenisnya (Sari \& Rachmawati, 2020). Jajanan yang kebersihannya tidak dapat dikontrol oleh pihak sekolah dan tidak terlindung serta tercemar oleh debu dan kotoran yang mengandung telur cacing, bakteri atau mikroorganisme lainnya dapat menjadi sumber penularan infeksi kecacingan, disentri dan infeksi penyakit lainnya pada anak. Selain melalui tangan, transmisi penyakit dapat juga melalui makanan dan minuman, terutama jajanan yang tidak dikemas dan tidak tertutup rapat.

Selain kontaminasi mikrobiologis, kontaminasi kimiawi yang umum ditemukan pada makanan jajanan kaki lima adalah penggunaan BTP ilegal seperti boraks formalin, rhodamin $B$, dan methanil yellow. Dalam jangka panjang bahan-bahan ini menyebabkan penyakit kanker dan tumor serta mempengaruhi fungsi otak termasuk gangguan perilaku pada anak sekolah. Pengaruh jangka pendek penggunaan BTP ini menimbulkan gejala- seperti pusing, mual, muntah, diare atau kesulitan BAB. Adanya kontaminasi kimiawi ini dibuktikan dalam penelitian observasional yang dilakukan di 68 SD yang berada di Kabupaten Bantul yaitu diperoleh hasil bahwa dari 98 sampel yang diuji kandungan boraks dan formalinnya, 15 sampel (15,3\%) positif mengandung boraks dan $25(25,5 \%)$ positif mengandung formalin dan dari 15 sampel yang diuji kandungan rhodamin-B, 7 sampel $(46,7 \%)$ positif mengandung rhodamin-B (Paratmanitya \& Veriani, 2016). Pada survey yang dilakukan terhadap Pedagang Kaki Lima (PKL) terungkap bahwa mereka tidak tahu adanya BTP ilegal pada bahan baku jajanan yang mereka jual. Selain itu, makanan yang dijajakan oleh PKL umumnya tidak dipersiapkan secara baik dan bersih. Dengan kondisi tersebut, maka perlu kerjasama 
yang baik dari berbagai pihak untuk mengatasi permasalahan kebiasaan jajan sembarangan pada anak yang berdampak pada kesehatan anak.

Kegiatan ini bertujuan untuk meningkatkan pengetahuan siswa SD tentang kandungan zat-zat kimia dalam jajanan serta bahaya zat tersebut bagi kesehatan dan kegiatan ini menggunakan metode penyuluhan berupa ceramah dan diskusi. Penelitian Maduretno Dkk (2015), menyatakan bahwa pemilihan jajanan sehat pada siswa kelas 5 SDN Tumpakrejo 2 meningkat setelah pemberian pendidikan gizi dengan metode ceramah serta pada siswa SD Tumpakrejo 1 juga mengalami peningkatan pemilihan jajanan sehat setelah diberikan pendidikan gizi dengan metode TGT (Team Game Tournament) (Maduretno et al., 2015). Sekolah dan pemerintah sebaiknya menyusun program untuk penelitian dan pengawasan terhadap pangan/jajanan anak di sekolah. Kalangan medis dan akademisi juga diharapkan dapat mengambil peran yang penting yaitu dengan memberikan penyuluhan tentang bahaya jajan sembarangan kepada pihak sekolah, orang tua murid dan juga siswasiswi SD. Diharapkan dengan adanya kerjasama yang baik dari semua pihak permasalahan kebiasaan jajan sembarangan dapat diatasi sehingga dengan pemberian asupan nutrisi yang terjamin kualitas dan kuantitasnya akan dapat meningkatkan kualitas generasi penerus bangsa Indonesia ke depan.

\section{METODE}

Kegiatan Penyuluhan dilaksanakan pada tanggal 15 Oktober 2016 di SDN 1 Petaling Kecamatan Mendo Barat Kabupaten Bangka. Khalayak sasaran adalah pada kegiatan ini adalah siswa-siswi kelas VI SDN 1 Petaling yang berjumlah 31 orang. Metode pengabdian yang digunakan adalah dengan memberikan penyuluhan dengan metode ceramah dan diskusi. Hal ini bertujuan untuk meningkatkan pengetahuan siswa-siswa tersebut tentang bahaya jajan sembarangan. Selain itu, penyampaian materi berbentuk video animasi tentang contoh akibat yang ditimbulkan karena jajan sembarangan dan cara memilih jajanan sehat sehari-hari. Kemudian dilanjutkan dengan permainan sebagai salah satu bentuk hasil dari analisis terhadap informasi yang telah disampaikan. Permainan mengkategorikan makanan jajanan sehat dan tidak sehat dengan gabus dan beberapa gambar makanan serta pin untuk melekatkan gambar tersebut diatas gabus. Penilaian permainan ini dilihat dari jumlah makanan jajanan yang benar dikategorikan menjadi makanan jajanan sehat dan tidak sehat oleh khalayak sasaran. Adapun penilaian keberhasilan penyampaian materi digunakan kuesioner pre dan post yang terdiri atas sebelas pertanyaan. Kuesioner yang digunakan berisi pertanyaan untuk mengukur pengetahuan siswa-siswa tentang jajanan dan dampaknya bagi kesehatan dengan menggunakan skala guttman

\section{HASIL DAN PEMBAHASAN}

Kegiatan pengabdian ini diikuti oleh 31 siswa-siswi SDN 1 Petaling kelas VI dengan menggunakan metode penyuluhan untuk memberikan pengetahuan pada khalayak sasaran tentang bahaya jajan sembarangan. Metode penyuluhan merupakan salah satu cara untuk meningkatkan pengetahuan gizi seseorang. Tujuan akhir dari penyuluhan yaitu adanya perubahan perilaku yang dilakukan secara edukatif (Nuryanto et al., 2014). Penyuluhan dalam kegiatan ini dilakukan dengan ceramah dan diskusi. Kelebihan dari metode ini yaitu relatif efisien dan sederhana serta mampu menjangkau banyak audiens dalam waktu bersamaan (Pratiwi Hartono et al., 2015). Pemberian ceramah dengan menggunakan audio visual yang menarik sangat membuahkan hasil belajar yang lebih baik untuk mengingat sehingga menimbulkan 
proses tanya jawab dan pada akhirnya siswa dapat menjawab kuesioner yang diberikan (Mardiana et al., 2012).

Menurut Rastini NK \& Marwati NM (2018), kekurangan penyuluhan dengan menggunakan metode ceramah yaitu semakin lama penyuluhan, penyuluh tidak bisa memberikan penilaian terhadap reaksi siswa dalam menangkap informasi yang disampaikan, serta pada saat menyampaikan materi yang berbentuk video, walaupun terlihat menarik namun kadang siswa terfokus dengan gambar yang tampil di video sehingga menyebabkan siswa tidak begitu menyerap informasi yang disampaikan dan hal ini membuat hasil posttest siswa ada yang masih sama dengan hasil pretest (Rastini \& Marwati, 2018). Penyampaian materi pada metode ini jika tidak diberikan secara baik dapat membuat responden merasa bosan (Kartini et al., 2019).

Kegiatan pengabdian ini diawali dengan menyanyikan lagu "Aku Anak Sehat" secara bersama dengan siswa (gambar 1). Selanjutnya dilakukan penilaian awal melalui kuesioner pre-test sebelum pelaksanaan penyuluhan. Kemudian dilanjutkan penyampaian materi dengan penyuluhan dan diskusi terkait akibat yang ditimbulkan karena jajan sembarangan dan cara memilih jajanan sehat sehari-hari (gambar 2). Sebelum acara berakhir, siswa diberikan posttest dengan menggunakan kuesioner yang sama dan diakhiri dengan permainan (gambar 3). Hal ini bertujuan untuk mengetahui tingkat keberhasilan penyuluhan. Melalui penyampaian materi dan permainan edukasi ini diharapkan adanya peran serta aktif dari pihak SDN 1 Petaling terutama siswa-siswi dalam upaya pencegahan jajan sembarangan sehingga mengurangi risiko kejadian penyakit akibat jajan sembarangan.
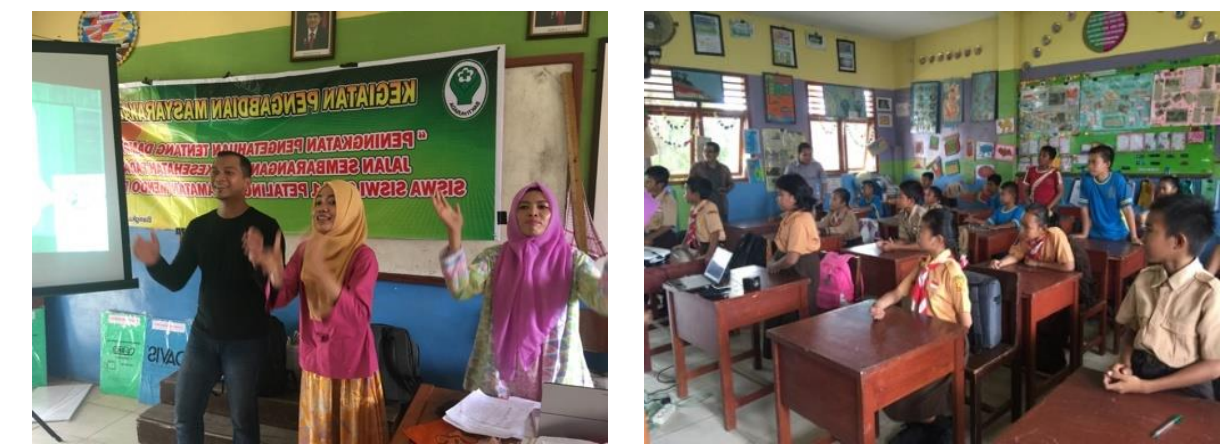

Gambar 1: Tim Penyuluhan (kiri) dan melakukan pemantauan (Kanan)
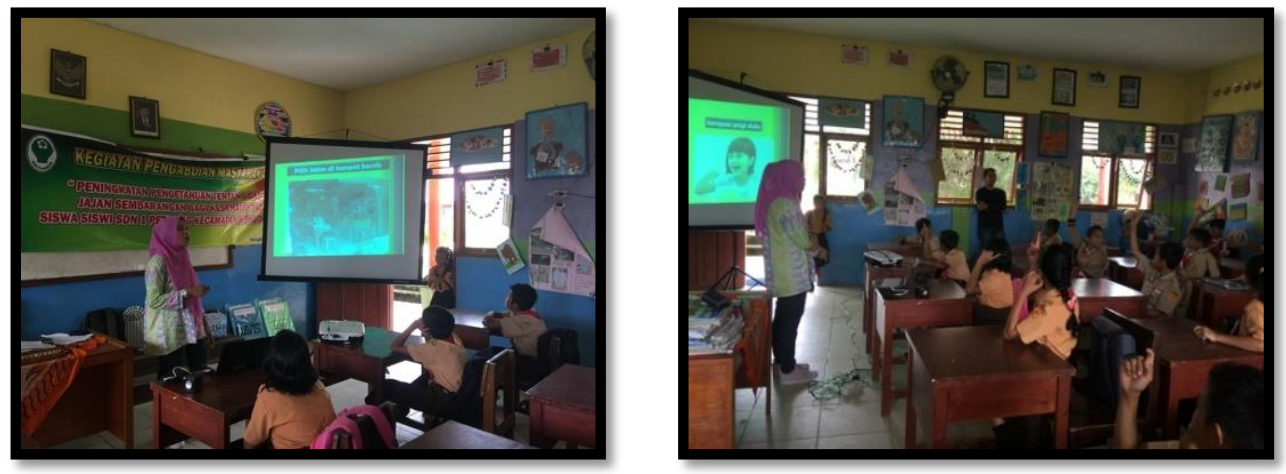

Gambar 2: Penyampaian materi (kiri) dan antusias siswa saat diskusi (Kanan) 

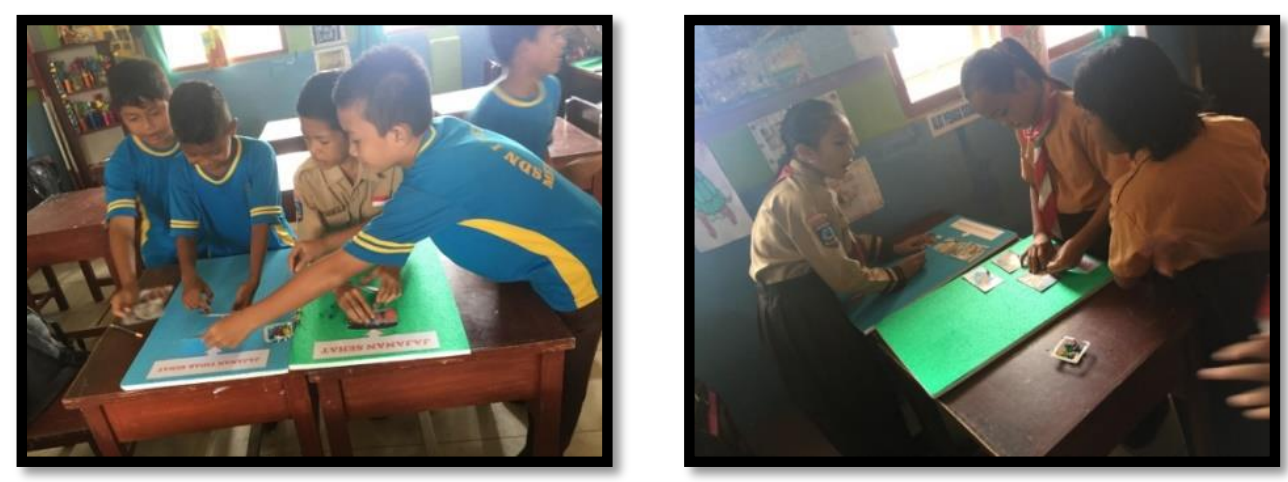

Gambar 3: Hasil permainan mengkategorikan makanan jajanan

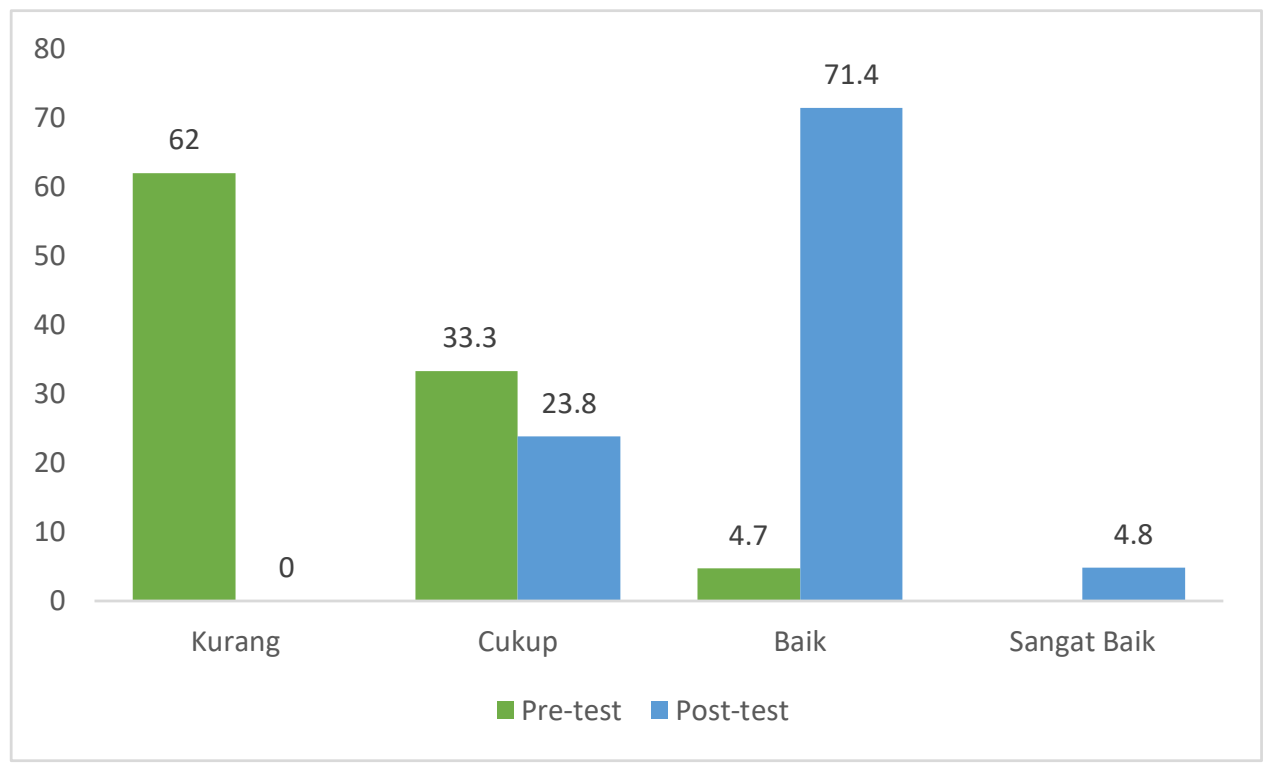

Gambar 4. Peningkatan pengetahuan hasil penyuluhan

Berdasarkan Gambar 4 terlihat data hasil pengamatan pretest, sekitar 4,7\% peserta yang memiliki pengetahuan kurang dan 33,3\% peserta telah mempunyai pengetahuan yang cukup serta $62 \%$ telah mempunyai pengetahuan yang baik. Setelah dilakukan kegiatan penyuluhan, nilai hasil pengamatan meningkat. Berdasarkan data hasil pengamatan posttest, diketahui bahwa $23,8 \%$ peserta cukup paham, $71,4 \%$ telah mempunyai pengetahuan yang baik dan $4,8 \%$ sangat baik. Berdasarkan hasil pengamatan di lapangan, jelas bahwa kegiatan penyuluhan tentang bahaya jajan sembarangan dapat dimengerti oleh peserta. Hal ini Dibuktikan melalui permainan memilih jajanan sehat dan tidak sehat, yakni salah satu kelompok dari tiga kelompok telah berhasil mengkategorikan makanan jajanan yang sehat dan tidak sehat dengan benar.

Hasil kegiatan pengabdian ini sejalan dengan hasil penelitian Briawan (2016), yang dilakukan terhadap 1.600 anak SD pada 13 Kabupaten/Kota dari 8 Provinsi di Indonesia. Hasil penelitiannya menyatakan bahwa sebelum program eduksi, tingkat pengetahuan tentang jajanan pada anak SD sebanyak 50,9\% termasuk kategori baik, $34,4 \%$ kategori sedang dan 14,7\% kategori kurang. Setelah dilakukan edukasi, terjadi peningkatan proporsi anak dengan tingkat pengetahuan baik sebesar 16,2\% (Briawan, 2016). Hasil kegiatan pengabdian ini juga sejalan dengan penelitian Nur \& Duanita 
(2019), yang menyatakan bahwa tingkat pengetahuan siswa Madrasah Ibtidaiyah AlFitrah Kupang sebelum diberikan penyuluhan mengenai jajanan sehat, responden memiliki tingkat pengetahuan baik sebanyak 23 orang $(37,7 \%)$ dan setelah diberikan penyuluhan, meningkat menjadi 43 orang (70,5\%) (Nur \& Duanita, 2019). Tingkat pengetahuan gizi yang beragam mengenai makanan jajanan siswa ini dapat disebabkan beberapa faktor, salah satunya adalah berasal dari sumber informasi gizi yang diterima siswa melalui orang tua, sekolah dan media cetak serta elektronik (Syafitri et al., 2009).

\section{SIMPULAN DAN SARAN}

Pengetahuan siswa sekolah dasar tentang bahaya jajan sembarangan meningkat yang terlihat dari nilai post-test yang lebih tinggi dibandingkan dengan nilai pre-test siswa-siswi. Berdasarkan hasil kegiatan yang telah dilakukan, bagi pihak Sekolah diharapkan hasil dari kegiatan ini dapat menjadi gambaran atau masukan agar dapat membuat kantin sehat di lingkungan sekolah sehingga makanan jajanan siswa-siswi dapat terjamin kualitasnya.

\section{DAFTAR PUSTAKA}

Briawan, D. (2016). Perubahan Pengetahuan Sikap Dan Praktik Jajanan Anak Sekolah Dasar Peserta Program Edukasi Pangan Jajanan. Jurnal Gizi Pangan, 13(3), 201-210. https://journal.ipb.ac.id/index.php/jgizipangan/article/view/16455

Kartini, T. D., Manjilala, M., \& Yuniawati, S. E. (2019). Pengaruh Penyuluhan terhadap Pengetahuan dan Praktik Gizi Seimbang pada Anak Sekolah Dasar. Media Gizi Pangan, 26(2), 201-208. https://doi.org/10.32382/mgp.v26i2.1231

Maduretno, I. S., Wirawan, N. N., \& Setijowati, N. (2015). Niat dan Perilaku Pemilihan Jajanan Anak Sekolah yang Mendapat Pendidikan Gizi Metode Ceramah dan TGT. Indonesian Journal of Human Nutrition, 2(1), 23-37. https://doi.org/10.21776/ub.ijhn.2015.002.01.3

Mardiana, M., Nilawati, N. S., \& Eliza, E. (2012). Pengaruh Penyuluhan Gizi Metode Ceramah dan Leaflet terhadap Perilaku Memilih Makanan Jajanan Murid di SD Negeri Kelurahan Sako Palembang. Jurnal Kesehatan Poltekkes Palembang2, 1(11), 17-23. https://jurnal.poltekkespalembang.ac.id/index.php/JPP/article/view/113

Mariza, Y. Y., \& Kusumastuti, A. C. (2013). Hubungan antara Kebiasaan Sarapan dan Kebiasaan Jajan dengan Status Gizi pada Anak Sekolah Dasar di Kecamatan Pedurungan Kota Semarang. Journal of Nutrition College, 2(1), 207-213. https://doi.org/10.14710/jnc.v2i1.2108

Nur, A., \& Duanita, M. H. (2019). Dampak Penyuluhan Jajanan Sehat Terhadap Pengetahuan Dan Sikap Anak Sekolah Dasar Di Madrasah Ibtidaiyah Al Fitrah Kampung Nelayan Oespa Kupang. CHMK Health Journal, 3(3), 62-68. https://cyberchmk.net/ojs/index.php/kesehatan/article/view/524/202

Nuryanto, N., Pramono, A., Puruhita, N., \& Muis, S. F. (2014). Pengaruh pendidikan gizi terhadap pengetahuan dan sikap tentang gizi anak Sekolah Dasar. Jurnal Gizi Indonesia (The Indonesian Journal of Nutrition), 3(1), 32-36. https://doi.org/10.14710/jgi.3.1.121125

Paratmanitya, Y., \& Veriani, A. (2016). Kandungan bahan tambahan pangan berbahaya pada makanan jajanan anak sekolah dasar di Kabupaten Bantul. Jurnal Gizi Dan Dietetik Indonesia (Indonesian Journal of Nutrition and Dietetics), 4(1), 49-55. https://doi.org/10.21927/ijnd.2016.4(1).49-55

Pratiwi Hartono, N., Saptaning Wilujeng, C., \& Andarini, S. (2015). Pendidikan Gizi tentang Pengetahuan Pemilihan Jajanan Sehat antara Metode Ceramah dan Metode Komik. Indonesian Journal of Human Nutrition, 2(2), 76-84. https://doi.org/10.21776/ub.ijhn.2015.002.02.2

Rastini, N. K., \& Marwati, N. M. (2018). Perbedaan Penggunaan Metode Ceramah Dengan Metode Ceramah Kombinasi Media Video Terhadap Pengetahuan Dan Tindakan Cuci 
Tangan Pakai Sabun Siswa. Jurnal Kesehatan Lingkungan, 8(1), 13-22. https://ejournal.poltekkes-denpasar.ac.id/index.php/JKL/article/view/344

Sari, Y. D., \& Rachmawati, R. (2020). Kontribusi Zat Gizi Makanan Jajanan terhadap Asupan Energi Sehari di Indonesia. Penelitian Gizi Dan Makanan (The Journal of Nutrition and Food Research), 43(1), 29-40. https://doi.org/10.22435/pgm.v43i1.2891

Sembiring, N., \& Ampera, D. (2018). Jurnal Pendidikan Teknologi dan Kejuruan: Vol. 20 No. 1 April 2018. Jurnal Pendidikan Teknologi Dan Kejuruan, 20(1), 6-14. https://jurnal.unimed.ac.id/2012/index.php/mbt/issue/download/1373/43

Syafitri, Y., Syarief, H., \& Baliwati, Y. F. (2009). Kebiasaan Jajan Siswa Sekolah Dasar (Studi Kasus di SDN Lawanggintung 01 Kota Bogor). Jurnal Gizi Dan Pangan, 4(3), 167-175. https://doi.org/10.25182/jgp.2009.4.3.167-175

Syam, A., Indriasari, R., \& Ibnu, I. (2018). Gambaran Pengetahuan dan Sikap Siswa terhadap Makanan Jajanan Sebelum dan Setelah Pemberian Edukasi Kartu Kwartet Pada Anak Usia Sekolah Dasar di Kota Makassar. JURNAL TEPAT : Applied Technology Journal for Community Engagement and Services, 1(2), 127-136. https://doi.org/10.25042/jurnal_tepat.v1i2.36 